\title{
Indicators of Organizational Support in Implementing Maternal and Child Health Information System
}

\author{
Heru Santoso Wahito Nugroho', Stefanus Supriyanto ${ }^{2}$, Hari Basuki Notobroto ${ }^{3}$ \\ ${ }^{1,2,3}$ Faculty of Public Health, Airlangga University, Indonesia
}

\section{Article Info}

Article history:

Received Jun 12, 2016

Revised Aug 19, 2016

Accepted Aug 26, 201

\section{Keyword:}

Confirmatory factor analysis

Health information system

Organizational support

Supervisor support

Work condition

\begin{abstract}
Nowadays, the implementation of health information system in Indonesia still encounters a number of obstacles e.g. redundant data, activities duplication, data quality, data not in harmony with the necessities, report not submitted on time, unoptimized feedback, low information utilization, and inefficient resources. This research aimed to analyze the indicators of organizational support which were suspected as one of the obstacles of the implementation of Maternal and Child Health Information System in Health Office of Ngawi Regency. The population of this cross sectional research was all village midwives administratively in duty in the areas of Ngawi Regency in 2015. Data was taken from all member of population through questionnaire filling, which was then analyzed by using confirmatory factor analysis (CFA). The result of data analysis suggested that the coefficient value that has been standardized from each indicators were as follows: supervisor support $=0.82$, work condition $=0.80$, and reard $=0.90$. Indicators of organizational support in implementing Maternal and Child Health Information System at Ngawi Regency Health Office, respectively from the most important are: reward, supervisor support, and work condition.
\end{abstract}

Copyright $@ 2016$ Institute of Advanced Engineering and Science. All rights reserved.

\section{Corresponding Author:}

Heru Santoso Wahito Nugroho,

Doctoral Student at Faculty of Public Health,

Airlangga University,

001/002, Dare, Sukorejo, Ponorogo, Jawa Timur, Indonesia, 63318.

Email: heruswn@gmail.com

\section{INTRODUCTION}

In line with the rise of information age, management of information technology-supported health information has been widely implemented. Nowadays, a number of hospitals, health offices and community health centers have utilized information technology to support working process in the organization, e.g. hospital information system, community health center information system, and also health office information system [1]. Since the dawn of decentralization in 2004, the utilization of information-technology based health information system is often not based upon standard guidelines (each institution uses their own version). This eventually leads to difficulties in the process of data recapitulation in provincial level [2].

The result of evaluation in 2010 suggested that the amount of "stand alone" Health Information System which was then integrated with other information systems generate duplicates in recording and reporting. This is proven with the fact that there were 301 types of reports from 8 different softwares of health information system as reported by provincial health office [2].

A big problem in the recent implementation of health information system is that there has been yet any manifestation of efficiency which was marked with: 1) the occurrence of redundant daya, 2) duplicated activities, 3) low data quality, 4) data is not in line with the necessities, 5) report not submitted on time, 6) unoptimized feedback system, 7) low data and information utilization in regency level for the purpose of advocating, program planning, monitoring, and management; and 8) inefficient resources utilization. Those 
conditions were due to: 1) overlapping in data gathering and data processing, 2) data and information processing have not been yet well integrated and well coordinated.

One of the organizations having implemented health information system is Ngawi Regency Health Office. One of the integrated feature of it is Maternal and Child Health Information System. The result of initial study through interview with the administrator team of Maternal and Child Health Information System suggested that in the past 5 years (2010-2014) there has been a decreasing trend of the implementation of information system in community health center. It has affected the system in regency health office level.

Based on the aforementioned empirical problem, it was deemed necessary to conduct a research concerning organizational support to village midwives as system user, especially concerning supervisor support, conducive work condition, and incentives related with the operational of the system.

\section{RESEARCH METHOD}

The population of this cross-sectional study was all village midwives administratively in duty in Health Department of Ngawi Regency in 2015 (population size=217). All of the village midwives included as a research subject, so there was no sampling process. Data was gathered through questionnaire filling regarding perceived organizational support, consisting of 3 indicators i.e. 1) supervisor support, 2) work condition, and 3) reward. After data was gathered, it was then processed and analyzed by using confirmatory factor analysis.

\section{RESULTS}

Result of multivariate data normality test by using confirmatory factor analysis (Table 1) suggested $\mathrm{CR}=-0.277$ (<1.96), that it could be concluded that by means of multivariate the data was normally distributed, that the result of confirmatory factor analysis can be used.

Table 1. Result of Multivariate Data Normality Test

\begin{tabular}{ccccccc}
\hline Variable & Minimum & Maximum & Skewness & Critical ratio & Kurtosis & Critical ratio \\
\hline pos3 (reward) & 1,000 & 8,000 & -.069 & -.414 & -.594 & -1.786 \\
pos2 (work condition) & 1,000 & 8,000 & -.432 & -2.597 & -.350 & -1.051 \\
pos1 (supervisor support) & 1,000 & 8,000 & -.211 & -1.270 & -.247 & -.741 \\
Multivariate & & & & & -.206 & -.277 \\
\hline
\end{tabular}

Result of research suggested that co-efficients for each observed variables (indicators) were respectivelly as follows: supervisor support $=0,82$, work condition $=0,80$, dan incentive $=0,90$. The whole coefficient value was approaching 1 , that it can be concluded that three of which were significant indicators for perceived organizational support (Figure 1).

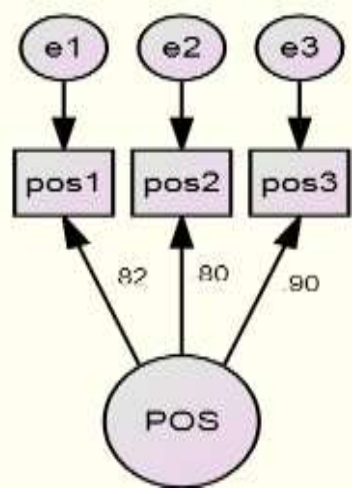

Figure 1. Result of confirmatory factor analysis

Standardized regression weight and P-value for each indicatoors were as follows: 1) supervisor support=0,815 \&<0.001, work condition=0,796 \&<0,001, and reward=0,902 \&<0,001. Since the P-value of 
all indicators were less than 0.05 , it can be concluded that supervisor support, work condition, and reward are valid indicators for perceived organizational support.

Variance error and P-value for each indicators were as follows: 1) supervisor support=1.000 $\&<0.001$, work condition=0.781 \&<0.001, and reward=0.503 \&<0.001. Since the P-value of all indicators were less than 0,05 , it can be concluded that supervisor support, work condition, and reward are reliable indicators for perceived organizational support.

\section{DISCUSSION}

In the implementation of information systems (including health information systems), there are several factors that must be taken to ensure that the system can be accepted by users. Besides technical factors such as the perceived usefulness and perceived ease of use [3], organizational factors such as the organizational support should also be considered [4]. Organizational support in this context is the support given by organizations to their employees, especially on matters relating to the implementation of information systems. In this case, the support given to employees who have been carrying out their role as users of information systems.

There are several important dimensions of perceived organizational support include fairness of treatment, supervisor support, rewards, and work conditions [5]. In the context of information systemimplementation, the manifestation of fairness of treatment is fair treatment to employees in the implementation of information systems; supervisor support can be realized in the form of encouragement from supervisors and managers of information systems to employees. Reward can be given in the form of incentives, while work condition can be achieved by creating a conducive environment to study the system, among other things: informational support (operational support), instrumental support (support in problem solving), and effective communication [4].

This research has analyzed the three indicators of the perceived organizational support, i.e. supervisor support, work condition, and reward. Result of analysis suggested that those three indicators are valid and reliable as the parameters of perceived organizational support.Several previous researches also reportes that perceived organizational support plays important role as a determinant of the acceptance of information system, besides other determinants, among others are: ease of use, usefulness, attitude toward use dan behavioral intention to use [4],[6]-[13].

First indicator that has been proven as valid and reliable, supervisor support, has been studied by previous researchers and were called with various terms, such as: top management encouragement/ management support/ peers \& supervisor support [4],[14]. Even though the indicator is called in different terms, it basically has the same essence i.e. positive encouragement from supervisors to the users in the framework of operationalization of information system.

Second indicator that has been proven as valid and reliable, work condition, has also been studied by previous researchers, with more diverse components, i.e.: communication with co-worker, a good communication with colleagues using the information system [4], help desk, help support for troubleshooting [4],[15], and allocation of resources, i.e. the provision of supporting resources for he operationalization of information system [14]. Those three indicators from different researchers have been accommodated into one indicator in this research, work condition.Third indicator that has been proven as valid and reliable is reward, which has also been studied by previous researchers, they called it as reward or incentive i.e. reward and incentives given to the user of information system [15]. Based on the comparatiom with previous researches, it could be said that supervisor support, work condition, and reward were truly the proper indicators to measure organizational support to the users in the framework of implementing health information system.

Perceived organizational support has an important position in the implementation of health information systems, as these factors can directly affect the actual system use [10]. If the supervisors and managers of information systems can provide guidance is actively and can conduct control is tight, then automatically the users will be conditioned to always actively implementing information systems, in the sense conditioned to immediately or not delaying the implementation of the system, run the system regularly, and maintain sustainability in the implementation of health information systems.

\section{CONCLUSION}

Based on results of data analysis it can be concluded that the indicators of organizational support in implementing Maternal and Child Health Information System at Ngawi Regency Health Office, respectively from the most important are: reward, supervisor support, and work condition. 


\section{REFERENCES}

[1] G. Y. Sanjaya, "National health information systems: strengthening the competence of health information system employee in Indonesia, through collaboration with universities," Window of Data And Health Information, Quarterly III, pp. 14-19, 2011.

[2] Health Ministry of Republic of Indonesia, "Decision of the Minister of Health of the Republic of Indonesia, No. 192/MENKES/SK/VI/2012, About Roadmap of Action Plan for Strengthening of Health Information Systems of Indonesia," Jakarta, health Ministry of Republic of Indonesia, 2012.

[3] F. D. Davis, R. P. Bagozzi, P. R. Warshaw, "User acceptance of computer technology: a comparison of two theoretical models," Management Science, vol. 36, pp. 982-1003, 1989.

[4] D. H. Lee, S. M. Lee, D. L. Olson, "The effect of organizational support on ERP implementation," Industrial Management \& Data Systems, vol/issue: 110(2), pp. 269-283, 2010.

[5] L. Rhoades, R. Eisenberger, "Perceived organizational support: a review of literature," Journal of Applied Psychology, vol/issue: 87(4), pp. 698-714, 2002.

[6] Y. H. Chuo, C. H. Tsai, Y. L. Lan, C. S. Tsai, "The effect of organizational support, self efficacy, and computer anxiety on the usage intention of e-learning," African Journal of Business Management, vol/issue: 5(14), pp. 55185523, 2011.

[7] C. P. H. Ernst, J. Pfeiffer, F. Rothlauf, "The influence of perceived belonging on social network site adoption," Proceedings of the Nineteenth Americas Conference on Information Systems, Chicago Illinois, pp. 15-17, 2013.

[8] E. Kurkinen, "Effect of enjoyment on attitude and on behavioral intention to use mobile applications when technology use IS mandatory," Jyväskylä, University of Jyväskylä, 2014.

[9] J. Macharia, E. Nyakwende, "Vice-chancellors influence on academic staff intentions to use learning management systems (LMS) for teaching and learning," The Journal of Language, Technology \& Entrepreneurship in Africa, vol/issue: 2(1), pp. 220-230, 2010.

[10] D. J. Mcfarland, D. Hamilton, "Adding contextual specificity to the technology acceptance model," Computers in Human Behavior, vol. 22, pp. 427-447, 2006.

[11] Mitchel, "The role of perceived organizational support, distributive justice and motivationin reactions to new information technology," Computer in Human Behavior, vol. 28, pp. 729-738, 2012.

[12] Y. Y. Shih, S. S. Huang, "The actual usage of erp systems: an extended technology acceptance perspective," Journal of Research and Practice in Information Technology, vol/issue: 41(3), pp. 263-276, 2009.

[13] E. Snicker, "Employee self-service technology acceptance: a case study at tap Portugal," Dissertation, Faculdade de Engenharia da Universidadedo Porto, 2013.

[14] M. Igbaria, J. Iivari, "The effect of self efficacy on computer usage," Journal of Management Science, vol/issue: 23(66), pp. 587-605, 1995

[15] C. Nayakkara, D. Whiddett, "A model of user acceptance of e-learning technologies: a case study of a polytechnic in New Zealand," 4th International Conference of Information Systems Technology and Its Application, Palmerston North, ISTA, pp. 180-189, 2005. 